\title{
21. Studies on the Secretor (Type v) and Non-Secretor (Type V) of Group Specific Agglutinin and Their Inheritance
}

\author{
By Tanemoto Furuhata, M.J.A., Kazuo Nakamura, \\ Hachiro NaKaJima, and Mitsue Suzuki \\ Department of Legal Medicine, Tokyo Medical and Dental University \\ (Comm. Feb. 12, 1959)
}

In $1928 \mathrm{~K}$. Yoshida ${ }^{1)}$ found group specific agglutinins (anti-A and anti-B agglutinins) in human saliva. From the systematic investigation in $1951 \mathrm{H}$. Miyakoshi ${ }^{2)}$ classified human subjects into secretors (type v) and non-secretors (type V) of agglutinins. He also found that type $\mathrm{v}$ showed a single recessive inheritance against type $\mathrm{V}$. The present report is concerned with the results obtained from further investigations of the classification and the hereditary relations.

Method. Agglutination was performed at room temperature (19$22^{\circ} \mathrm{C}$ ) for 45 minutes by the slide method. One drop of $2 \%$ cells suspension of A and B blood groups was added to one drop of previously diluted saliva. When the group specific agglutinins were not found in the original saliva, the saliva was condensed at $50^{\circ} \mathrm{C}$ water bath until the concentration became one-eighth the original quantity, and after two-fold dilution the titer of the group specific agglutinin was read.

Experimental results. 1) The distribution of titers of anti-A and anti-B agglutinins in saliva and the classification of types $\mathrm{V}$ and $\mathrm{v}$. As shown in Figs. 1 and 2, both titers of anti-A and anti-B agglutinins

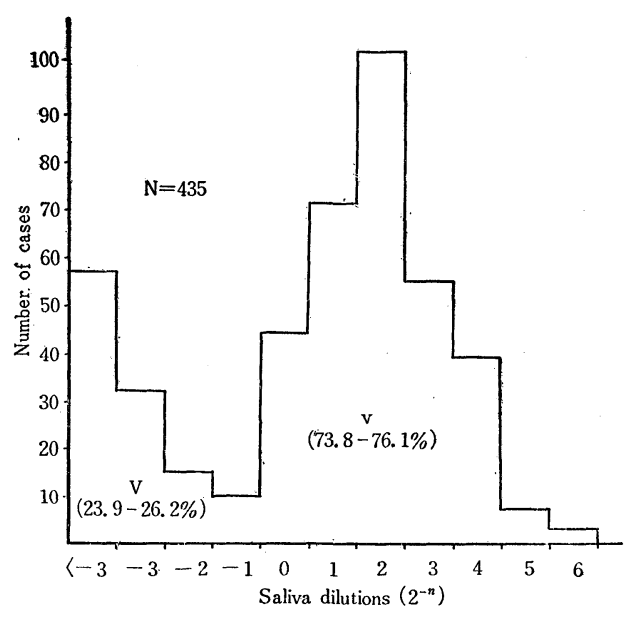

Fig. 1. Histogram of the titer of anti-B agglutinin in group $\mathrm{A}$ and group $\mathrm{O}$ human saliva

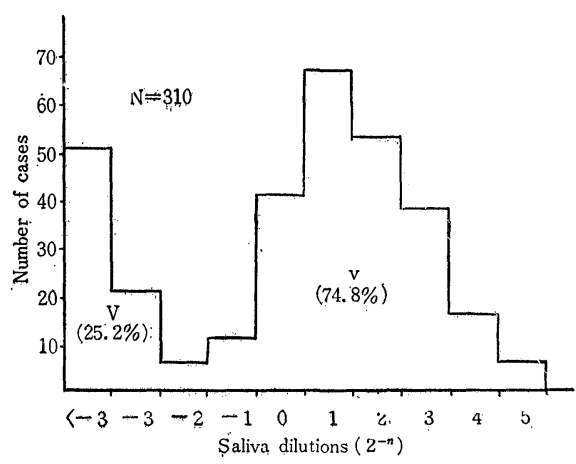

Fig. 2. Histogram of the titer of antiA agglutinin in group B and group $O$ human saliva 
in saliva indicated bimodal distributions. Human saliva was examined with 561 subjects and they were 251 subjects of blood group A, 126 of blood group B, and 184 of blood group 0 .

Based upon the above investigation the authors could classify subjects of blood groups O, A, and B into two groups, i.e. type V and type v. After establishing the statistical rejection limits for the distributions of Figs. 1 and 2, the following percents were obtained for types $\mathrm{V}$ and $\mathrm{V}$ respectively.

a) Titers of anti-B agglutinin in saliva of blood groups $\mathrm{A}$ and $\mathrm{O}$ individuals

Type V (titer. $\cdot<-3 \sim-1) \cdot \cdot \cdot \cdot 23.9-26.6 \%$

Type v (titer... $-1 \sim 6) \cdot . \cdot . \cdot 73.8-76.1 \%$

b) Titers of anti-A agglutinin in saliva of blood groups $\mathrm{B}$ and $\mathrm{O}$

Type V (titer..<-3 - 2 ) . • $25.2 \%$

Type v (titer... $-1 \sim 5) \cdot . . . \cdot 74.8 \%$

2) The heredity of group specific agglutinins in saliva. The hereditary relations of types $\mathrm{V}$ and $\mathrm{v}$ were investigated by examining the salivary anti-B agglutinin in 165 children of 83 families, the blood

Table I. Family data of anti-B agglutinin

$(\mathrm{A} \times \mathrm{A}, \mathrm{A} \times \mathrm{O}$, and $\mathrm{O} \times \mathrm{O}$ matings $)$

\begin{tabular}{c|c|c|c|r|r|r|r}
\hline \multirow{2}{*}{ Mating } & $\begin{array}{c}\text { Number } \\
\text { of } \\
\text { families }\end{array}$ & \multicolumn{5}{|c|}{ Offspring } & Total \\
\cline { 3 - 6 } & Obs. no. & Exp. no. & Obs. no. & Exp. no. & \multicolumn{2}{|c|}{$\mathrm{V}$} \\
\hline $\mathrm{V} \times \mathrm{V}$ & 8 & $10(76.9 \%)$ & $10.2(78.4 \%)$ & $3(23.1 \%)$ & $2.8(21.6 \%)$ & 13 \\
$\mathrm{~V} \times \mathrm{v}$ & 34 & $31(50.0 \%)$ & $33.2(53.5 \%)$ & $31(50.0 \%)$ & $28.8(46.5 \%)$ & 62 \\
$\mathrm{~V} \times \mathrm{v}$ & 41 & - & - & $90(100 \%)$ & $90.0(100 \%)$ & 90 \\
\hline Total & 83 & 41 & - & 124 & - & 165 \\
\hline
\end{tabular}

Table II. Family data of anti-A agglutinin $(\mathrm{B} \times \mathrm{B}, \mathrm{B} \times \mathrm{O}$, and $\mathrm{O} \times \mathrm{O}$ matings $)$

\begin{tabular}{c|c|c|c|r|r|r}
\hline \multirow{2}{*}{ Mating } & $\begin{array}{c}\text { Number } \\
\text { of } \\
\text { families }\end{array}$ & \multicolumn{5}{|c|}{ Offspring } \\
\cline { 3 - 7 } & Obs. no. & Exp. no. & Obs. no. & Exp. no. & . Total \\
$\mathrm{V} \times \mathrm{V}$ & 6 & $11(78.5 \%)$ & $11.0(78.5 \%)$ & $3(21.5 \%)$ & $3.0(21.5 \%)$ & 14 \\
$\mathrm{~V} \times \mathrm{v}$ & 20 & $16(45.7 \%)$ & $18.8(53.6 \%)$ & $19(54.3 \%)$ & $16.2(46.4 \%)$ & 35 \\
$\mathrm{v} \times \mathrm{v}$ & 30 & - & - & $62(100 \%)$ & $62.0(100 \%)$ & 62 \\
\hline Total & 56 & 27 & - & 84 & - & 111 \\
\hline
\end{tabular}


group combinations of their parents being $\mathrm{A} \times \mathrm{A}, \mathrm{A} \times 0$, or $0 \times 0$.

The results are summarized in Table I. As shown by the table the both types $\mathrm{V}$ and $\mathrm{v}$ were found among the children when the blood group combinations of their parents were $\mathrm{V} \times \mathrm{V}$ or $\mathrm{V} \times \mathrm{v}$. However, only type $\mathrm{v}$ was found when the combination of the parents was $\mathrm{v} \times \mathrm{v}$. These results confirmed the single recessive inheritance of type $\mathrm{v}$ against type $\mathrm{V}$.

A similar investigation was performed with anti-A agglutinin in saliva of 111 children from 56 families, there parents combinations being $\mathrm{B} \times \mathrm{B}, \mathrm{B} \times \mathrm{O}$, or $\mathrm{O} \times \mathrm{O}$ (Table II). The results also confirmed the same type of inheritance.

Summary. Based upon the group specific agglutinins (anti-A and anti-B agglutinins) in saliva, blood groups $\mathrm{A}, \mathrm{B}$, and $\mathrm{O}$ subjects can be classified into two groups; the secretor (type $\mathrm{v}$ ) and the non-secretor (type $\mathrm{V}$ ), and the former is concluded to be inherited by single recessive inheritance against the latter.

\section{References}

1) Yoshida, K.,: Shakai Igaku Zasshi, 495, 331-347 (1928).

2) Miyakoshi, H.,: Jap. J. Leg. Med., 5 (6), 75-100 (1951). 